\title{
Knowledge, attitude and practices of contraception among married women
}

\author{
Bhabani Pegu', Bhanu Pratap Singh Gaur ${ }^{2} *$, Nalini Sharma ${ }^{1}$, Ahanthem Santa Singh ${ }^{1}$ \\ ${ }^{1}$ Department of Obstetrics \& Gynaecology, NEIGRIHMS, Shillong, Meghalaya, India \\ ${ }^{2}$ Department of Community Medicine, NEIGRIHMS, Shillong, Meghalaya, India \\ Received: 9 April 2014 \\ Accepted: 3 May 2014 \\ *Correspondence: \\ Dr. Bhanu Pratap Singh Gaur, \\ E-mail: bhanuamc@gmail.com \\ (C) 2014 Pegu B et al. This is an open-access article distributed under the terms of the Creative Commons Attribution \\ Non-Commercial License, which permits unrestricted non-commercial use, distribution, and reproduction in any \\ medium, provided the original work is properly cited.
}

\begin{abstract}
Background: Aim of current study was to assess the knowledge, attitude \& practices of contraceptives among married women of reproductive age group.

Methods: A cross sectional study was conducted in obstetrics \& gynaecology (obs. \& gynae) out door patient department (OPD), North Eastern Indira Gandhi Regional Institute of Health \& Medical Sciences, Shillong, Meghalaya. 200 married women aged between 15-45 years were included in this study. Along with the sociodemographic characteristics of the women, their knowledge, attitude and practices on contraception were evaluated with the help of predesigned questionnaire.

Results: It was observed that out of 200 women, majority of them were Christian (52\%), illiterate (26.5\%), housewife $(43.5 \%)$ and belong to low socio economic status (31.5\%). $174(87 \%)$ had knowledge about contraceptive methods and it was mainly obtained from health workers $(58.6 \%)$ followed by media $(24.1 \%)$ and social circle $(15.5 \%)$. 76 (38\%)women were practicing contraceptive methods, out of which most of them were using condom (38.2\%) followed by Oral Contraceptive Pills (OCPs) (27.6\%), intra uterine contraceptive device (15.8\%) etc. Though most of the women had knowledge about contraceptive methods majority of male $55.5 \%$ and female $51.5 \%$ were showing negative attitude towards family planning.

Conclusions: The study showed, inspite of having good knowledge, utilization of contraceptives were less because of large family norm, religious myth, cultural \& political barrier.
\end{abstract}

Keywords: Knowledge, Attitude, Practice, Contraception

\section{INTRODUCTION}

Uncontrolled population explosion is a burden on resources of many developing countries. Of the world population, $75 \%$ live in developing countries characterized by high fertility rate, high maternal \& infant mortality rate and low life expectancy. ${ }^{1}$ The world population will likely to increase by 2.5 billion over the next 43 years, passing from the current 6.7 billion to 9.2 billion in $2050 .{ }^{2}$ Birth spacing not only reduce fertility but also improve health of the mother. The leading causes of death among reproductive age women are due to complications arising during pregnancy and child birth.
Each year approximately 55,000 women die in India due to pregnancy or childbirth-related complications. ${ }^{3}$

According to WHO, family planning is defined as`a way of thinking and living that is adopted voluntarily, upon the basis of knowledge, attitude and responsible decisions by individuals and couples, in order to promote the health and welfare of family group and thus contribute effectively to the social development of a country." National family planning program was first launched in India in 1951 , with aim to reduce the birth rate to stabilize the population. ${ }^{4}$ 
In developing countries Couple Protection Rate (CPR) is still very less. According to national family welfare statistics 2011, CPR in India is 40.4\%. In Pakistan CPR was $30 \%$ in 2011 while most developed country like USA has $71 \%$ CPR for all methods. 5,6 ,

Now a days fertility rate has come down due to wide spread use of family planning methods, whereas some developing countries like India, Pakistan, the use of contraception is still low because of lack of awareness, education, religion, cultural, economic and political barrier. ${ }^{7}$ Proper counseling for family planning necessary because $27 \%$ of women are at risk of unplanned pregnancy. 8

\section{METHODS}

This cross-section study was conducted in obs. \& gynae OPD, NEIGRIHMS, Shillong. 200 married women aged between 15-45 years were interviewed. Along with the socio-demographic characteristics of the women, their knowledge, attitude and practices on contraception were evaluated with the help of predesigned questionnaire. Questionnaire also enquired about source of knowledge regarding contraception whether they obtained from media, health worker, social circle, family members, friends etc.

Exclusion criteria were pregnant women, infertility and patients having any medical disorder.

\section{RESULTS}

The study shows, mean age of respondent was $29.8 \pm$ 7.28. All the socio-demographic characteristics of responders were described in Table 1.

Table 2 shows knowledge regarding different contraceptive methods. Out of 200 women, 174 (87\%) had knowledge about family planning. Majority of them $73(42 \%)$ knew about condom, followed by OCPs \& other methods.

The women who had knowledge about contraceptive methods, they mainly obtained from health workers $58.6 \%$, followed by media and social circle. Distribution of source of knowledge regarding different methods is shown in Table 3.

Table 4 shows attitude of male and female regarding contraceptives. Though majority of women had knowledge about family planning methods most of the male and female had negative attitude towards contraceptives.

Out of all the different methods of contraception commonly practicing method was condom followed by OCPs \& others. Table 5 shows practices of different contraceptive methods.
Table 1: Socio demographic characteristics of respondent.

\begin{tabular}{|c|c|}
\hline & Frequency (\%) \\
\hline \multicolumn{2}{|l|}{ Age (in years) } \\
\hline $15-19$ & $19(9.5)$ \\
\hline $20-30$ & $96(48)$ \\
\hline $31-40$ & $57(28.5)$ \\
\hline$>40$ & $28(14)$ \\
\hline \multicolumn{2}{|l|}{ Religion } \\
\hline Christian & $104(52)$ \\
\hline Hindu & $49(24.5)$ \\
\hline Muslim & $36(18)$ \\
\hline Others & $11(5.5)$ \\
\hline \multicolumn{2}{|c|}{ Education status (woman) } \\
\hline Illiterate & $53(26.5)$ \\
\hline Primary & $40(20)$ \\
\hline High school & $41(20.5)$ \\
\hline Higher secondary & $46(23)$ \\
\hline Graduate $\&$ above & $20(10)$ \\
\hline \multicolumn{2}{|c|}{ Education status (husband) } \\
\hline Illiterate & $25(12.5)$ \\
\hline Primary & $45(22.5)$ \\
\hline High school & $48(24)$ \\
\hline Higher secondary & $62(31)$ \\
\hline Graduate \& above & $20(10)$ \\
\hline \multicolumn{2}{|c|}{ Occupation (woman) } \\
\hline Govt. employee & $23(11.5)$ \\
\hline Private employee & $48(24)$ \\
\hline Daily wage earner & $42(21)$ \\
\hline House wife & $87(43.5)$ \\
\hline \multicolumn{2}{|c|}{ Family Income (monthly in Rs.) } \\
\hline Below 5000 & $63(31.5)$ \\
\hline $5001-10000$ & $38(19)$ \\
\hline $10001-15000$ & $58(29)$ \\
\hline$>15000$ & $41(20.5)$ \\
\hline \multicolumn{2}{|l|}{ Number of children } \\
\hline One & $22(11)$ \\
\hline Two & $48(24)$ \\
\hline Three & $73(36.5)$ \\
\hline$>$ Four & $57(28.5)$ \\
\hline
\end{tabular}

Table 2: Knowledge regarding different contraceptive methods.

\begin{tabular}{|lll|}
\hline $\begin{array}{l}\text { Contraceptive } \\
\text { methods }\end{array}$ & $\begin{array}{l}\text { Number } \\
(\mathbf{n = 1 7 4})\end{array}$ & $\begin{array}{l}\text { Percentage } \\
(\%)\end{array}$ \\
\hline Condom & 73 & 42 \\
\hline OCPs & 40 & 23 \\
\hline Copper T (IUCD) & 26 & 14.9 \\
\hline Injectable device & 15 & 8.6 \\
\hline Tubectomy & 20 & 11.5 \\
\hline
\end{tabular}


Table 3: Source of knowledge.

\begin{tabular}{|lll|}
\hline Source & $\begin{array}{l}\text { Number } \\
(\mathbf{n = 1 7 4})\end{array}$ & $\begin{array}{l}\text { Percentage } \\
(\%)\end{array}$ \\
\hline Health worker & 102 & 58.6 \\
\hline Media & 42 & 24.1 \\
\hline Social circle & 27 & 15.5 \\
\hline Others & 3 & 1.7 \\
\hline
\end{tabular}

Table 4: Attitude towards contraception.

\begin{tabular}{|llll|}
\hline Attitude & Users $(\mathbf{n = 7 6 )}$ & $\begin{array}{l}\text { Non users } \\
(\mathbf{n = 1 2 4})\end{array}$ & Total \\
\cline { 1 - 3 } Female & Number $(\boldsymbol{\%})$ & Number $(\%)$ & \\
\hline Positive & $55(72.4)$ & $42(33.9)$ & $97(48.5 \%)$ \\
\hline Negative & $21(27.6)$ & $82(66.1)$ & $103(51.5 \%)$ \\
\hline Male & & & \\
\hline Positive & $35(46.1)$ & $54(43.5)$ & $89(44.5 \%)$ \\
\hline Negative & $41(53.9)$ & $70(56.5)$ & $111(55.5 \%)$ \\
\hline
\end{tabular}

Table 5: Practices of contraception.

\begin{tabular}{|lll|}
\hline $\begin{array}{l}\text { Contraceptive } \\
\text { method }\end{array}$ & $\begin{array}{l}\text { Number } \\
(\mathbf{n = 7 6})\end{array}$ & $\begin{array}{l}\text { Percentage } \\
(\%)\end{array}$ \\
\hline Condom & 29 & 38.2 \\
\hline OCPs & 21 & 27.6 \\
\hline IUCD & 12 & 15.8 \\
\hline Tubectomy & 8 & 10.5 \\
\hline Injectable device & 6 & 7.9 \\
\hline
\end{tabular}

\section{DISCUSSION}

Strategies to increase contraceptive use must include improving delivery of correct and adequate information about the availability of contraceptive methods. ${ }^{9}$ Education of women is considered to be a most important factor in decision making. ${ }^{10}$ For contraceptive usage, woman's will and motivation is necessary. Awareness and knowledge is the key to choose the right method for contraception. In our study, result showed that $87 \%$ women had knowledge about contraception whereas 97.4 $\& 99 \%$ is seen in other studies conducted at Lahore. ${ }^{11,12}$

The findings are contradicting with the study conducted in 2011 at Bhopal by Mahawar P et al. ${ }^{13}$ In 2009, another study conducted in Andhra Pradesh among Racha Koya women, $81 \%$ had knowledge on different contraceptive methods. $^{14}$

Major source of knowledge regarding contraceptives were health worker $(58.6 \%)$ followed by media $24.1 \%$, social circle $15.5 \%$ and others. Similar result seen in study conducted in Ethiopia, showed that $80.3 \%$ of health worker contributed in disseminating information regarding contraception. ${ }^{15}$ Another study conducted by Omo-Aghoja et al. from Nigeria in 2009, and Srivastava et al. from India in 2005, social circle was found to be the main source of knowledge \& followed by health worker. ${ }^{16,17}$ While another study showed media as a main source of information. ${ }^{18}$

In present study, $62 \%$ of women were not using any method of contraception whereas 55\% had never used contraceptives in study conducted by Srivastava et al. in 2005, India ${ }^{17}$ and $8 \%$ in Young et al study done in New Zealand. $^{19}$

In this study, condom was the most common method $(38.2 \%)$. Similar results were shown in other study as well. $^{20-22}$ In contrast, study conducted by Musarrat Jabeen et al., commonly used methods were traditional, injectable \& female sterilization which is different from the work of Seema et al. ${ }^{6,7}$

Though majority of women had knowledge about contraceptives only $48.5 \%$ female and $44.5 \%$ male had positive attitude towards contraception as stated by their wives, whereas study conducted by Zangmu Sherpa et al., $87.5 \%$ had positive attitude. ${ }^{23} 78 \%$ and $74 \%$ of husband approved the use of contraceptives in other Studies conducted in Sindh and Punjab respectively. ${ }^{24,25}$ Similar result was seen in the study done by Sonia Naqvi et al. ${ }^{26}$

Family planning services need to provide a range of quality method that can allow women to either limit or space birth and to fulfill the need of women with differing socio-demographic characteristics. ${ }^{27}$ In our study though majority of interviewer women had knowledge about family planning methods but practicing is still low because of lack of education, cultural, religion, economical and political barriers.

\section{CONCLUSIONS}

Inspite of having good knowledge about family planning methods \& positive attitude there are some factors like desire for large family, pressure from husband, religious concern etc. lead to non-use of contraceptives. So this is important to improve educational status of the female to overcome these barriers and increase the uptake of modern contraceptive methods.

\section{ACKNOWLEDGEMENTS}

We are very grateful to all the faculties of the obstetrics $\&$ gynaecology department \& colleagues, for their help \& co-operation in completing this small piece of work.

Funding: No funding sources

Conflict of interest: None declared

Ethical approval: The study was approved by the institutional ethics committee

\section{REFERENCES}

1. Population Reference Bureau. World Population Data Sheet, 2010. Available at: http://www.prb.org/pdf10/10wpds_eng.pdf. 
2. Hammad AQ, Hashmi A, Syed AR, Jamil AS, Aslam G. Contraceptive methods and factors associated with modern contraceptive in use. J Family Reprod Health. 2010;4:41-6.

3. Rai SK, Dasgupta R, Das MK, Singh S, Devi R, Arora NK. Determinants of utilization of services under MMJSSA scheme in Jharkhand 'client perspective': a qualitative study in a low performing state of India. Indian J Pub Health. 2011;55:252-9.

4. K. Park. Chapter 9. In: K. Park, eds. Text Book of Preventive \& Social Medicine. 21st ed. Jabalpur: Banarsidas Bhanot; 2011: 445.

5. WHO. Reproductive health indicator-guidelines for their generation, interpretation and analysis for global monitoring. In: WHO, eds. WHO Guideline. Geneva. WHO, Reproductive Health and Research; 2006: 1-63.

6. Bibi S, Memon A, Memon Z. Contraceptive knowledge and practices in two districts of Sindh Pakistan-A hospital based survey. JPMA. 2008;58:254-7.

7. Musarrat Jabeen, Fouzia Gul, Farmanullah Wazir, Nargis Javed. Knowledge, attitude and practices of Contraception in women of reproductive age. Gomal J Med Sci. 2011;9(2):223-9.

8. Tsui AO, McDonald-Mosley R, Burke AE. Family planning and the burden of unintended pregnancies. Epidemiol Rev. 2010;32:152-74.

9. Kaushal SK, Saxena SC, Srivastava VK, Gupta SC, Nigam S. KAP study on contraceptive methods in Kanpur district of UP. Indian J Commun Health. 2009-2010;21(2):33-8.

10. Cindoglu D, Sirkeci I, Sirkeci RF. Determinants of choosing withdrawal over modern contraceptive methods in Turkey. Eur J Contracept Reprod Health Care .2008;13:412-21.

11. Hakim A, Sultan M, Ahmed F. Pakistan reproductive health and family planning survey 2001. In: Hakim A, Sultan M, Ahmed F, eds. The Institute. Islamabad: The Institute; 2001: 60-62.

12. Humayun S. Knowledge and practices of family planning in grandmultiparas. J Coll Physicians Surg Pak. 2002;12:522-5.

13. Mahawar P, Anand S, Raghunath D, Dixit S. Contraceptive knowledge, attitude and practices in mothers of infant: a cross-sectional study. National J Commun Med. 2011;2:171-4.

14. Rao PD,Babu MS. Knowledge and use of contraception among Racha Koyas of Andhra Pradesh. Anthropol. 2005;7:115-9.

15. Senbeto E. A study on knowledge, attitude, practice and quality of care in family planning at Dessie Zuria District. J Ethiop Med Pract. 2001;3:70-6.
16. Chigbu B, Onwere S. Aluka C, Kamanu C, Okoro O, Feyl-Waboso P. Contraceptive choices of women in rural Southern Nigeria. Niger J Clin Pract. 2010;13:195-9.

17. Srivastava R, Srivastava DK, Jina R, Srivastava K, Sharma N, Sana S. Contraceptive knowledge, attitude and practice (KAP Survey). J Obstet Gynaecol India. 2005;55:546-50.

18. Sultan K, Younus S. Mass media and family planning: understanding the effects of television in innovation decision process of health communication in district Peshawar. KUST Med J. 2010;2:58-63.

19. Renjhen P, Gupta SD, Barua A, Jaju S and Khati B. A study of knowledge, attitude and practice of family planning among the women of reproductive age group in Sikkim. J Obstet Gynaecol India. 2008;58:63-7.

20. Khawaja NP, Tayyab R, Malik N. Awareness and practices of contraception among Pakistani women attending a tertiary care hospital. J Obstet Gynaecol 2004;24:564-7.

21. Oyedeji OA, Cassimjee R. A gendered study of young adult contraceptive use at one university in Kwa Zulu-Natal. Curationis. 2006;29(3):7-14.

22. Brahmbhatt MM, Sheth JK, Balaramanamma DV. A study of knowledge, attitude \& practice towards contraception among married women of reproductive age group having $\leq 2$ children residing in Vasna ward, Ahmedabad, Gujarat, India. Healthline. 2013;4(2):8-12.

23. Sherpa SZ, Sheilini M, Nayak A. Knowledge, attitude, practice and preferences of contraceptive methods in Udupi district, Karnataka. J Family Reprod Health. 2013;7(3):115-20.

24. Ali S, White FMM. Family planning practices among currently married women in Khairpur District, Sindh, Pakistan. J Coll Physicians Surg Pak. 2005;15:422-5.

25. Khawaja NP, Tayyab R, Malik N. Awareness and practices of contraception among Pakistani women attending a tertiary care hospital. J Obstet Gynaecol. 2004;24:564-7.

26. Naqvi S, Hashim $\mathrm{N}$, Zareen $\mathrm{N}$, Fatima $\mathrm{H}$. Knowledge, attitude and practice of parous women regarding contraception. J Coll Physicians Surg Pak 2011; 21(2): 103-105.

27. Rozina M, Uzma A, Haleema AH. Contraceptive knowledge, attitude and practice among rural women. J Coll Physicians Surg Pak. 2008;18(9):5425 .

DOI: $10.5455 / 2320-1770 . i j r \operatorname{cog} 20140620$

Cite this article as: Pegu B, Gaur BPS, Sharma N, Singh AS. Knowledge, attitude and practices of contraception among married women. Int J Reprod Contracept Obstet Gynecol 2014;3:385-8. 